BACKGROUND: Interleukin-6 (IL-6), a pluripotent cytokine, has traditionally been considered the product of proinflammatory cells. However, many other cell types have been shown to produce IL-6. Since intestinal inflammation is commonly associated with a vigorous systemic inflammatory response, we hypothesized that intestinal epithelial and smooth muscle cells might contribute to that response by producing IL-6. We therefore studied the capacity of differentiated human intestinal epithelial and smooth muscle cell lines to produce IL-6 in response to various proinflammatory stimuli.

Materials and methods: CCL-241, a human intestinal epithelial cell line, and HISM, a human intestinal muscle cell line, were grown to confluency and then treated for $24 \mathrm{~h}$ with various concentrations of lipopolysaccharide, Clostridium difficile culture extract containing both toxin $A$ and toxin $B$, recombinant human tumor necrosis factor-alpha (TNF- $\alpha$ ), or recombinant human interleukin-1 beta (IL-1ß). Supernatants were then collected for IL-6 determination using an enzyme-linked immunosorbent assay. Cell numbers were determined using a Coulter counter. For comparison, parallel studies were performed using phorbol ester-primed U-937 and THP-1 human macrophage cell lines.

Results: Both human intestinal epithelial and smooth muscle cells produced IL- 6 under basal conditions. In HISM cells, but not in CCL-241 cells, IL-6 release was increased slightly by treatment with $C$. difficile culture extract containing both toxin $A$ and toxin $B$ and with lipopolysaccharide. In both cell lines, IL-6 production was profoundly stimulated by treatment

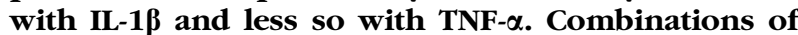

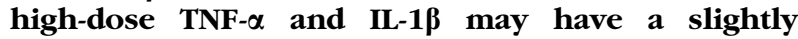
additive, but not synergistic, effect on IL-6 release. The amount of IL- 6 produced by IL-1-stimulated intestinal cell lines was $\mathbf{7 0}$-fold higher than that produced by stimulated macrophage cell lines.

Conclusions: Both intestinal epithelial and smooth muscle cells demonstrate the ability to release significant amounts of IL-6. The profound response to IL-1 $\beta$ and TNF- $\alpha$ stimulation by both cell lines suggests that human intestinal parenchymal cells, influenced by paracrine mediators liberated from proinflammatory cells, might significantly contribute to the overall systemic inflammatory response by producing IL-6.

Key words: Interleukein-6, Interleukin-1, Tumor necrosis factor, Cytokines, Intestine, Epithelium, Smooth muscle, CCL-241, HISM

\section{Human intestinal epithelial and smooth muscle cells are potent producers of IL-6}

\author{
Edmond K. Ng${ }^{1}$, Ninder Panesar ${ }^{1}$, Walter \\ E. Longo ${ }^{1,2}$, Marc J. Shapiro ${ }^{1}$, Donald L. Kaminski ${ }^{1}$, \\ Kym C. Tolman ${ }^{1}$ and John E. Mazuski ${ }^{1-3, C A}$
}

${ }^{1}$ Department of Surgery, Saint Louis University School of Medicine, St Louis, Missouri, USA; ${ }^{2}$ Department of Surgery, DVA Medical Center, St Louis, Missouri, USA; and ${ }^{3}$ Department of Surgery, Washington University School of Medicine, Campus Box 8109, 660 S. Euclid Avenue, St Louis, Missouri 63110-1093, USA

\footnotetext{
${ }^{\mathrm{CA}}$ Corresponding author

Tel: + 13143625307

Fax: + 13143625743

E-mail: mazuskij@msnotes.wustl.edu
}

\section{Introduction}

Interleukin-6 (IL-6) is a pluripotent cytokine that is involved in multiple inflammatory processes. IL-6 acts as a pyrogen, mediates B-cell proliferation and immunogloblin secretion, and is a primary stimulus for the synthesis of hepatic acute phase proteins. ${ }^{1-5}$ It is also associated with several alterations related to the metabolic stress of the systemic inflammatory state, such as the development of cachexia and anorexia, and stimulation of the hypothalamicpituitary-adrenal axis by increasing adrenocorticotropin hormone and cortisol release. It is also involved in regulating the secretion of other hormones, including growth hormone and thyroidstimulating hormone. ${ }^{6,7}$ IL-6 may also have anti- 
inflammatory effects since it downregulates interleukin-1 beta (IL-1 $\beta$ ) and tumor necrosis factor-alpha (TNF- $\alpha$ ) secretion, which are known stimulators of IL6 production. $^{7}$

Although IL-6 production has often been attributed to proinflammatory cells such as macrophages, it has been demonstrated that IL- 6 can be produced by many other cells, such as neurons, glial cells, adipose cells, fibroblasts, osteocytes, hepatocytes, endothelial cells, and a variety of other epithelial cells. ${ }^{6-16}$ In fact, IL-6 was initially identified as interferon $\mathrm{N}$ produced by fibroblasts and as hepatocyte stimulatory factor produced by a cervical carcinoma cell line. ${ }^{1,8}$

Intestinal cells may likewise be an important source of IL-6. IL- 6 produced in the intestine may be of significance not only in the local regulation of intestinal immunologic and defense functions, but also could contribute to the development of the systemic inflammatory response. It has been shown that IL- 6 production by the intestinal mucosa is upregulated in a number of intestinal disease states, including ischemia/reperfusion (I/R) injury, chronic rejection following small bowel transplantation and inflammatory bowel disease. ${ }^{17-20}$ Mucosal specimens taken from patients with inflammatory bowel disease exhibit enhanced IL-6 production, ${ }^{21-32}$ but the cellular origin of IL-6 is unclear. While there is debate, a few reports have suggested that IL- 6 production comes directly from the intestinal epithelial cells ${ }^{33-36}$ or from smooth muscle cells. ${ }^{37-39}$ To more clearly document the potential contribution of intestinal epithelial and smooth muscle cells to local and systemic IL-6 production, we studied IL-6 release by pure cultures of these cells. Additionally, since IL-6 release is stimulated by a variety of exogenous bacterial products as well as endogenous inflammatory mediators, ${ }^{7,10,11}$ we studied the responses of these cells to a variety of different agents, both alone and in combination.

\section{Methods}

\section{Cell lines}

CCL-241, a human intestinal epithelial cell line derived from normal human fetal tissues, and HISM, a human intestinal smooth muscle cell line isolated from jejunal muscularis propria of a normal adult female, were utilized. Two monocytic cell lines, U937, a monocyte cell line derived from histiocytic lymphoma, and THP-1, a monocyte cell line isolated from acute monocytic leukemia, were activated by pretreatment for $48 \mathrm{~h}$ with 40 and $16 \mathrm{nM}$ of $12-\mathrm{O}-$ tetradecanoylphorbol-13-acetate (Sigma, St Louis, MO, USA) to induce attachment and macrophage differentiation. ${ }^{40,41}$ CCL-241 and HISM were grown on 24-well plates in Dulbecco's modified Eagle's medium (Sigma) with 10\% fetal bovine serum (Sigma) and U-937 and THP-1 in RPMI 1640 medium (Sigma) with 10\% fetal bovine serum. Media was changed (or added for the monocytic cell lines prior to attachment induced by phorbol esters) every $2-3$ days and were split at confluency or subcultured at $1 \times 10^{6}$ cells $/ \mathrm{ml}$ as assessed by cell counting using a hemocytometer. All cells were maintained in a $37^{\circ} \mathrm{C}$ incubator in an atmosphere of 95\% air and 5\% $\mathrm{CO}_{2}$.

\section{IL-6 production}

At confluency, cultures were treated for $24 \mathrm{~h}$ with culture medium containing various concentrations of a Clostridium difficile culture extract (TechLab, Blacksburg, VA, USA), which contains both toxin A and B, lipopolysaccharide (LPS) (Eschericha coli 0111:B4; Difco Laboratories, Detroit, MI, USA), recombinant human IL-1 $\beta$ (R\&D Systems, Inc., Minneapolis, MN, USA), or recombinant human TNF- $\alpha$ (R\&D Systems, Inc.). Supernatants were removed and centrifuged at $1000 \mathrm{~g} \times 5 \mathrm{~min}$ to remove detached cells and were stored at $-80^{\circ} \mathrm{C}$ for subsequent IL-6 determination. Phosphate-buffered saline containing trypsin was added to detach adherent cells, and the cells were centrifuged at $1000 \mathrm{~g} \times 5 \mathrm{~min}$ and resuspended in phosphate-buffered saline for determination of cell numbers using a Coulter counter. Sandwich enzyme-linked immunosorbent assay (ELISA) for human IL-6 was performed according to the manufacturer's directions. This was based on the DuoSet ELISA Development System (R\&D Systems, Inc.), which utilizes a mouse anti-human IL-6 capture antibody, a biotinylated goat anti-human IL-6 detection antibody, horseradish peroxidase-conjugated streptavidin, and $\mathrm{H}_{2} \mathrm{O}_{2}$ /tetramethylbenzidine as the peroxidase substrate. Samples were read using a dual wavelength spectrophotometer (450 $\mathrm{nm}$ reading, 540 $\mathrm{nm}$ correction), and the amount of IL- 6 was calculated using a standard curve prepared with known amounts of purified recombinant human IL-6. According to the specifications provided by the manufacturer, the sensitivity of the assay for IL- 6 in culture supernatants was $0.70 \mathrm{pg} / \mathrm{ml}$. No significant crossreactivity or interference was observed with other cytokines or inhibitors, including leukemia inhibitory factor and interleukin-11. In repetitive testing, intraassay coefficients of variation ranged from 1.7 to 4.4 and inter-assay coefficients of variation ranged from 2.0 to 3.7 .

\section{Statistical methods}

Measurements represent mean \pm standard error of the mean. The amounts of IL-6 produced under different conditions were compared within each cell line using a paired $t$-test with Bonferroni correction for multiple 
comparisons with control values. The unpaired $t$-test was utilized for comparisons between cell lines.

\section{Results}

CCL-241 release of IL-6 following treatment with C. difficile toxin, LPS, IL-1 $\beta$, and TNF- $\alpha$

The human intestinal epithelial cell line released detectable amounts of IL- 6 into the culture medium under basal conditions (Table 1). Neither $C$. difficile toxins nor LPS stimulated IL- 6 release. Both IL- $1 \beta$ and TNF- $\alpha$ stimulated IL- 6 release in a dose-dependent manner. TNF- $\alpha$ produced a 10 -fold increase in IL-6 release, while IL-1 $\beta$ elicited a 150 -fold increase in IL-6 release. Cells stimulated with high concentrations of both IL-1 $\beta$ and TNF- $\alpha$ produced greater amounts of IL-6 than those stimulated with either cytokine alone, although this was not statistically significant (Table 2). However, combinations of IL- $1 \beta$ and TNF- $\alpha$ at lower concentrations $(2.0 \mathrm{U} / \mathrm{ml}$ and $1 \mathrm{ng} / \mathrm{ml}$, respectively) elicited a seven-fold increase in IL-6 production compared with that produced by either cytokine alone.

\section{HISM release of IL- 6 following treatment with $C$. difficile toxin, LPS, IL-1 $\beta$, and TNF- $\alpha$}

The human intestinal smooth muscle cell released 14fold higher amounts of IL- 6 under basal conditions than did the CCL-241 cells (Table 1). C. difficile toxins and LPS stimulated slight increases in IL-6 release, although these did not reach statistical significance. As with CCL-241 cells, both TNF- $\alpha$ and IL-1 $\beta$ stimulated IL- 6 release in a dose-dependent manner. TNF- $\alpha$ increased IL-6 release approximately four-fold but IL-1 $\beta$ elicited a greater than 10-fold increase in IL-6 release. Combinations of high-dose IL- $1 \beta$ and TNF- $\alpha$ also resulted in a slight augmentation of IL- 6 release compared with that of IL- $1 \beta$ alone, although these were not statistically significant (Table 2 ). Additionally, combinations of lower concentrations of IL-1 $\beta$ and TNF- $\alpha(2.0 \mathrm{U} / \mathrm{ml}$ and $1 \mathrm{ng} / \mathrm{ml}$, respectively) did not give rise to increased IL-6 release compared with that produced by either cytokine alone.

\section{Macrophage release of IL- 6 following treatment with $C$. difficile toxin, LPS, IL-1 $1 \beta$, and TNF- $\alpha$}

Under basal conditions, U-937 cells released small amounts of IL-6. However, the amounts of IL-6 produced by THP-1 cells were insufficient for detection using the ELISA. $C$. difficile toxins, IL-1 $\beta$, and TNF- $\alpha$ elicited no further stimulation of IL-6 in U-937 cells. LPS, however, increased IL-6 production 50 -fold in U-937 cells and stimulated THP-1 cells to produce detectable levels of IL-6 (Table 2). It is notable that the maximum amount of IL-6 produced by these macrophage cell lines was 100-fold less than that produced by maximally stimulated CCL-241 or HISM cells.

Table 1. Effects of various stimuli on IL-6 production by CCL-241 cells, and on IL- 6 release by HISM cells and by macrophage cell lines

IL-6 production by CCL-241 cells IL- 6 release by HISM cells IL- 6 release by macrophage cell lines

\begin{tabular}{|c|c|c|c|c|}
\hline Stimulator & IL-6 (pg/1000 cells) & IL-6 (pg/1000 cells) & U-937 & THP-1 \\
\hline None & $10 \pm 10$ & $150 \pm 60$ & $0.5 \pm 0.3$ & N.D. \\
\hline $\mathrm{CdT}\left(1: 2 \times 10^{7}\right)$ & $9 \pm 8$ & $140 \pm 70$ & $0.5 \pm 0.4$ & N.D. \\
\hline CdT $\left(1: 2 \times 10^{6}\right)$ & $7+6$ & $180+85$ & $0.5+0.3$ & N.D. \\
\hline $\mathrm{CdT}\left(1: 2 \times 10^{5}\right)$ & $5 \pm 5$ & $160 \pm 80$ & $0.5 \pm 0.3$ & N.D. \\
\hline $\mathrm{CdT}\left(1: 2 \times 10^{4}\right)$ & $4 \pm 4$ & $270 \pm 170$ & $0.5 \pm 0.3$ & N.D. \\
\hline CdT $\left(1: 2 \times 10^{3}\right)$ & $11 \pm 15$ & $540 \pm 490$ & $0.6 \pm 0.3$ & N.D. \\
\hline LPS $(0.001 \mu \mathrm{g} / \mathrm{ml})$ & $10 \pm 10$ & $165 \pm 75$ & $2 \pm 1$ & $0.1 \pm 0.0$ \\
\hline LPS $(0.01 \mu \mathrm{g} / \mathrm{ml})$ & $8 \pm 5$ & $160 \pm 70$ & $6 \pm 2 *$ & $1 \pm 0.2$ \\
\hline LPS $(0.1 \mu \mathrm{g} / \mathrm{ml})$ & $8 \pm 3$ & $190 \pm 90$ & $14 \pm 7^{*}$ & $5 \pm 1$ \\
\hline LPS $(1.0 \mu \mathrm{g} / \mathrm{ml})$ & $9+3$ & $250+160$ & $23+12 *$ & $10+4$ \\
\hline LPS $(10 \mu \mathrm{g} / \mathrm{ml})$ & $10 \pm 5$ & $230 \pm 116$ & $24 \pm 11 *$ & $11 \pm 4$ \\
\hline IL-1 $1 \beta(0.02 \mathrm{U} / \mathrm{ml}$ & $10 \pm 9$ & $170 \pm 90$ & $0.5 \pm 0.3$ & N.D. \\
\hline IL-1 $\beta(0.2 \mathrm{U} / \mathrm{ml}))$ & $20 \pm 13^{*}$ & $190 \pm 100$ & $0.5 \pm 0.3$ & N.D. \\
\hline $\mathrm{IL}-1 \beta(2.0 \mathrm{U} / \mathrm{ml})$ & $450 \pm 150 *$ & $270 \pm 125$ & $0.5 \pm 0.3$ & N.D. \\
\hline IL-1 $\beta(20 \mathrm{U} / \mathrm{ml})$ & $810 \pm 430^{*}$ & $1060 \pm 580^{*}$ & $0.5 \pm 0.3$ & N.D. \\
\hline IL-1 $\beta(200 \mathrm{U} / \mathrm{ml})$ & $1300 \pm 740 *$ & $2500 \pm 1100 *$ & $0.5 \pm 0.3$ & N.D. \\
\hline IL-1 $\beta(2000 \mathrm{U} / \mathrm{ml})$ & $1500 \pm 950 *$ & $2380 \pm 1200^{*}$ & $0.6 \pm 0.3$ & N.D. \\
\hline TNF- $\alpha(0.1 \mathrm{ng} / \mathrm{ml})$ & $27 \pm 20$ & $230 \pm 104$ & $0.5 \pm 0.3$ & N.D. \\
\hline TNF- $\alpha(1.0 \mathrm{ng} / \mathrm{ml})$ & $33 \pm 25^{*}$ & $382 \pm 226^{*}$ & $0.5 \pm 0.3$ & N.D. \\
\hline TNF- $\alpha(10 \mathrm{ng} / \mathrm{ml})$ & $70 \pm 41 *$ & $481 \pm 270^{*}$ & $0.5 \pm 0.3$ & N.D. \\
\hline TNF- $\alpha(100 \mathrm{ng} / \mathrm{ml})$ & $106 \pm 70^{*}$ & $560 \pm 385^{*}$ & $0.8 \pm 0.2$ & N.D. \\
\hline
\end{tabular}

$n=6$ experiments/condition, ${ }^{*} p<0.05$ versus control (with Bonferroni correction for multiple comparisons). CdT, $C$. difficile culture extract containing both toxin A and toxin B; N.D., not determined. 
Table 2. Effect of combined stimuli on IL-6 production

\begin{tabular}{|c|c|c|}
\hline & CCL-241 cells ${ }^{a}$ & HISM cells ${ }^{b}$ \\
\hline Stimulator & IL-6 (pg/1000 cells) & IL-6 (pg/1000 cells) \\
\hline None & $3 \pm 2$ & $130 \pm 50$ \\
\hline LPS $(10 \mu \mathrm{g} / \mathrm{ml})$ & $3 \pm 1$ & $223 \pm 90$ \\
\hline $\mathrm{IL}-1 \beta(2.0 \mathrm{U} / \mathrm{ml})$ & $32 \pm 14$ & $250 \pm 95$ \\
\hline IL-1 $13(200 \mathrm{U} / \mathrm{ml})$ & $862 \pm 357$ & $1400 \pm 615$ \\
\hline TNF- $\alpha(1.0 \mathrm{ng} / \mathrm{ml})$ & $33 \pm 8$ & $480 \pm 220$ \\
\hline TNF- $\alpha(100 \mathrm{ng} / \mathrm{ml})$ & $108 \pm 54$ & $700 \pm 400$ \\
\hline LPS and IL- $1 \beta(200 \mathrm{U} / \mathrm{ml})$ & $935 \pm 723$ & $1335 \pm 550$ \\
\hline LPS and TNF- $\alpha(100 \mathrm{ng} / \mathrm{ml})$ & $166 \pm 102$ & $1000 \pm 585$ \\
\hline LPS and TNF- $\alpha(100 \mathrm{ng} / \mathrm{ml})$ and IL-1 $\beta(200 \mathrm{U} / \mathrm{ml})$ & $1725 \pm 869$ & $2440 \pm 1140$ \\
\hline TNF- $\alpha(1.0 \mathrm{ng} / \mathrm{ml})$ and IL-1 $\beta(200 \mathrm{U} / \mathrm{ml})$ & $859 \pm 343$ & $2500 \pm 990$ \\
\hline TNF- $\alpha(100 \mathrm{ng} / \mathrm{ml})$ and IL- $1 \beta(2.0 \mathrm{U} / \mathrm{ml})$ & $391 \pm 188$ & $1100 \pm 740$ \\
\hline TNF- $\alpha(1.0 \mathrm{ng} / \mathrm{ml})$ and IL-1 $\beta(2 \mathrm{U} / \mathrm{ml})$ & $221 \pm 113^{*}$ & $525 \pm 260$ \\
\hline TNF- $\alpha(100 \mathrm{ng} / \mathrm{ml})$ and IL-1 $\beta(200 \mathrm{U} / \mathrm{ml})$ & $1251 \pm 511$ & $2470 \pm 1070$ \\
\hline
\end{tabular}

${ }^{a} n=4$ experiments/condition, ${ }^{*} p<0.05$ versus IL-1 $\beta(2.0 \mathrm{U} / \mathrm{ml})$ versus TNF- $\alpha(1.0 \mathrm{ng} / \mathrm{ml})$ (with Bonferroni correction for multiple comparisons). ${ }^{\mathrm{b}} n=6$ experiments/condition, no values reached statistical significance of $p<0.05$ versus appropriate control (with Bonferroni correction for multiple comparisons).

\section{Discussion}

IL-6 was originally identified on the basis of many different biologic activities and was variously called interferon- $\beta 2$, B-cell stimulatory factor $2,26 \mathrm{kDa}$ protein, hybridoma/plasmacytoma growth factor, hepatocyte stimulating factor, and monocyte granulocyte inducer type $2 .{ }^{1}$ IL- 6 and other cytokines that bind to the cellular IL- 6 receptor or the soluble IL-6 receptor have been implicated in the pathogenesis of a broad spectrum of disease processes, including Castleman's Syndrome and multiple myeloma, Kaposi's sarcoma-associated herpes virus-8 infection, thrombosis in myocardial infarction, myocardial cell hypertrophy in congestive heart failure, osteoporosis and other diseases with increased osteoclastic bone resorption, rheumatoid arthritis, systemic lupus erythematosis, and cancer-related anorexia/cachexia syndrome. $6,7,14,42-46$

In the gut, IL-6 has been linked to I/R injury, chronic rejection following small bowel transplantation, and both Crohn's disease and ulcerative colitis. ${ }^{17-20}$ In a rat intestinal I/R model, accumulation of IL-6 mRNA in the mucosa and muscularis externa was shown to precede immunohistochemical evidence of cellular I/R injury. ${ }^{17}$ In rat small intestinal transplants, in situ hybridization demonstrated the presence of increased mucosal and muscularis externa IL-6 mRNA in experimental chronic rejection. ${ }^{18}$

A number of clinical reports have also suggested a role of IL-6 in the pathogenesis of inflammatory bowel disease. Both patients with Crohn's disease and with ulcerative colitis have elevated amounts of IL-6 in the serum, ${ }^{47,48}$ in circulating and resident proinflammatory cells, ${ }^{49,50}$ and in mucosal samples. $^{21,22}$ While a number of studies have demonstrated increases in IL-6 production by mucosal biopsies, there has been little consensus with regard to the primary cellular source of IL-6. A few studies utilizing in situ hybridization for IL-6 mRNA or measuring IL-6 in Percoll gradient isolated intestinal epithelial and lamina propria mononuclear cells have suggested that the primary source of IL- 6 is from the lamina propria mononuclear cells. ${ }^{24-30}$

However, in one of these studies, in situ hybridization demonstrated greater amounts of IL- 6 message in the mucosa than in the lamina propria. ${ }^{30}$ Additionally, a different study using in situ hybridization demonstrated equally prominent IL- 6 expression in both areas. ${ }^{31}$ Finally, a study detecting IL-6 protein using immunohistochemistry/fluorescence demonstrated that IL-6 was predominantly present in the enterocytes and colonocytes of patients with inflammatory bowel disease. ${ }^{32}$ Therefore, it remains unclear whether one or both of these cell types are the most important contributors to IL-6 production during intestinal inflammation.

Although normal intestinal epithelial cells have been shown to express IL-6 receptors and to respond to IL- $6,{ }^{33}$ few studies have focused on the production of IL- 6 by pure intestinal epithelial cell lines. Goodrich and McGee have demonstrated that IL- 6 can be produced by cultured rat intestinal cells, ${ }^{34}$ and Strong et al. have shown that IL-6 mRNA is produced by primary cultures of human intestinal cells. ${ }^{35}$ However, Fayyazi et al. stated that IL-6 mRNA was undetectable in human colonic epithelium. ${ }^{36}$ There are also some studies suggesting that intestinal smooth muscle cells produce IL-6. In the rat intestine, and in cultured rat intestinal smooth muscle cells, IL$1 \beta$ and TNF- $\alpha$ were found to stimulate IL- 6 mRNA and IL- 6 production. ${ }^{37-39}$ Possible IL- 6 production by the intestinal smooth muscle cells could therefore correspond to the findings of significant IL-6 localization in the muscularis externa in animal models of $\mathrm{I} / \mathrm{R}$ injury and chronic rejection. ${ }^{17,18}$

In our studies, the representative human cell lines, CCL-241 and HISM, were potent producers of IL-6 
when stimulated by TNF- $\alpha$, and particularly by IL- $1 \beta$. Our findings correspond to other studies that have shown these cytokines to be the primary stimulators of IL- 6 production from other cell lines. ${ }^{8-13}$ IL-1 $\beta$ and TNF- $\alpha$ may have had slight additive effects on the amount of IL- 6 production, although this effect was not dramatic. The failure to demonstrate greater responses to combinations of these cytokines may indicate that both agents act through a common final mechanism to stimulate IL-6 production.

The amount of IL- 6 produced by the epithelial and smooth muscle cells was substantially greater than that produced by the macrophage cells. In addition, the stimuli eliciting IL-6 release were quite distinct; LPS was the most potent stimulator of macrophage IL-6 release, but it only slightly stimulated IL-6 release by intestinal smooth muscle cells and had no effect on intestinal epithelial cells. However, it might be anticipated that intestinal epithelial cells should not respond to LPS since these cells might normally be exposed to luminal endotoxin on a constant basis. Exposure to $C$. difficile toxins and LPS did seem to produce a trend towards increased IL- 6 production by the intestinal smooth muscles cells. This seems reasonable since these cells would not normally be exposed to luminal toxins in vivo.

Overall, the findings from these experiments clearly demonstrate that intestinal epithelial and smooth muscle cells have the capacity to produce 1L-6. It can be hypothesized that IL-6 production by these cells plays a role in the local and systemic inflammatory processes during intestinal diseases. An initiating factor (such as exposure of the lamina propria to endotoxin) could stimulate IL-1 $\beta$ and TNF- $\alpha$ production by the resident macrophages and other proinflammatory cells in the bowel wall. These cytokines could then stimulate intestinal epithelial cells and intestinal smooth muscle cells to produce IL-6. This IL-6, acting in a paracrine fashion, could modulate the local immunologic and inflammatory responses in the bowel wall. In addition, the IL-6 produced could also act in an endocrine fashion to augment the systemic inflammatory reaction. Thus, the resident parenchymal and mesenchymal cells of the bowel through their elaboration of mediators, such as IL-6, may be of importance in understanding the pathogenesis of intestinal diseases.

ACKNOWLEDGEMENTS. Partial funding provided by a Surgical Infection Society Resident Research Fellowship Grant, 1999-2000. Supported in part by a fellowship to Dr. Ng from the Surgical Infection Society.

\section{References}

1. Hirano T, Akira S, Taga T, Kishimoto T. Biological and clinical aspects of interleukin 6. Immuno Today 1990; 11: 443-449.

2. LeMay LG, Vander AJ, Kluger MJ. Role of interleukin- 6 in fever in rats. Am J Physiol 1990; 258: R798-R803.

3. Heinrich PC, Castell JV, Andus T. Interleukin- 6 and the acute phase response. Biochem J 1990; 265: 621-636.
4. Fey GH, Gauldie J. The acute phase response of the liver in inflammation. Prog Liver Dis 1990; 9: 89-116.

5. Mazuski JE, Tolman K, Shapiro MJ. Effects of cytokine antagonism on the hepatic acute-phase response. J Surg Res 1997; 68: 161-169.

6. Barkhudaryan N, Dunn AJ. Molecular mechanisms of actions of interleukin- 6 on the brain, with special reference to serotonin and the hypothalamo-pituitary adrenocortical axis. Neurochem Res 1999; 24 1169-1180.

7. Papanicolaou DA, Wilder RL, Manolagas SC, Chrousos GP. The pathophysiologic roles of interleukin-6 in human disease. Ann Intern Med 1998; 128: $127-137$.

8. Helfgott DC, May LT, Sthoeger Z, Tamm L, Schgal PB. Bacterial lipopolysaccharide (endotoxin) enhances expression and secretion of $\beta 2$ interferon by human fibroblasts. J Exp Med 1987; 166: 1300-1309.

9. Navarro S, Debili N, Bernaudin JF, Vainchenker W, Doly J. Regulation of the expression of IL-6 in human monocytes. J Immunol 1989; 142 $4339-4345$.

10. Sironi M, Breviario F, Proserpio P, et al . IL-1 stimulates IL-6 production in endothelial cells. J Immunol 1989; 142: 549-553.

11. Jirik FR, Podor TJ, Hirano T, Kishimoto T, Loskutoff DJ, Carson DA, Lotz M. Bacterial lipopolysaccharide and inflammatory mediators augment IL-6 secretion by human endothelial cells. J Immunol 1989; 142: $144-$ 147.

12. Kirnbauer R, Kock A, Schwarz T, et al. IFN- $\beta 2$, B-cell differentiation factor 2, or hybridoma growth factor (IL-6) is expressed and released by human epidermal cells and epidermoid carcinoma cell lines.J Immunol 1989; 142: $1922-1928$.

13. Callery MP, Kamei T, Flye MW. Endotoxin stimulates interleukin- 6 production by human Kupffer cells. Circ Shock 1992; 37: 185-188.

14. Manolagas SC. The role of 1L- 6 type cytokines and their receptors in bone. Ann NY Acad Sci 1998; 840: 194-204.

15. Panesar N, Tolman K, Mazuski JE. Endotoxin stimulates hepatocyte interleukin-6 production. J Surg Res 1999; 85: 251-258.

16. Fried SK, Bunkin DA, Greenberg AS. Omental and subcutaneous adipose tissues of obese subjects release interleukin-6: depot difference and regulation by glucocorticoid. J Clin Endocrinol Metab 1998; 83: $847-850$.

17. Hierholzer C, Kalff JC, Audolfsson G, Billiar TR, Tweardy DJ, Bauer AJ. Molecular and functional contractile sequelae of rat intestinal ischemia/ reperfusion injury. Transplantation 1999; 68: 1244-1254.

18. Hayashi M, Martinez OM, Krams SM, Burns W, Esquivel CO. Characterization of allograft rejection in an experimental model of small intestinal transplantation. J Gastrointest Surg 1998; 2: 325-332.

19. Walgenbach KJ, Heeckt PF, Kalff JC, Stanson J, Whiteside TL, Hirner A Bauer AJ. Increase of interleukin-6 in the intestinal mucosa and muscularis following chronic rejection after small bowel transplantation. Transplant Proc 1998; 30: 2600

20. McAlindon ME, Mahida YR. Pro-inflammatory cytokines in inflammatory bowel disease. Aliment Pharmacol Ther 1996; 10(Suppl 2): $72-74$.

21. Mitsuyama K, Sasaki E, Toyonaga A, et al . Colonic mucosal interleukin-6 in inflammatory bowel disease. Digestion 1991; 50: 104-111.

22. Sher ME, D'Angelo AJ, Stein TA, Bailey B, Burns G, Wise L. Cytokines in Crohn's colitis. Am J Surg 1995; 169: 133-136.

23. Ishiguro Y. Mucosal proinflammatory eytokine production correlates with endoscopic activity of ulcerative colitis. J Gastroenterol 1999; 34 $66-74$.

24. Grottrup-Wolfers E, Moeller J, Karbach U, Muller-Lissner S, Endres S Elevated cell-associated levels of interleukin ibcta and interleukin 6 in inflamed mucosa of inflammatory bowel disease. Eur J Clin Invest 1996; 26: $115-122$

25. Reimund JM, Wittersheim C, Dumont S, et al. Increased production of tumour necrosis factor-alpha interleukin-1 beta, and interleukin- 6 by morphologically normal intestinal biopsies from patients with Crohn's disease. Gut 1996; 39: 684-689.

26. Jones SC, Crabtree JE, Rembacken BJ, Dixon MF, Trejdosiewicz LK, Whicher JT, Axon ATR. Mucosal interleukin-6 secretion in ulcerative colitis. Effects of anti-inflammatory drugs and T-cell stimulation. Scand J Gastroenterol 1994; 29: 722-728.

27. Reinecker HC, Steffen M, Witthoeft T, Pflueger I, Schreiber S, MacDermott RP, Raedler A. Enhanced secretion of tumour necrosis factor-alpha, IL-6, and IL- 1 beta by isolated lamina propria mononuclear cells from patients with ulcerative colitis and Crohn's disease. Clin Exp Immunol 1993; 94: $174-181$

28. Arai F, Takahashi T, Furukawa K, Matsushima K, Asakura H. Mucosal expression of interleukin-6 and interleukin-8 messenger RNA in ulcerative colitis and in Crohn's disease. Dig Dis Sci 1998; 43: $2071-$ 2079.

29. Hosokawa T, Kusugami K, Ina K, et al. Interleukin- 6 and soluble interleukin 6 receptor in the colonic mucosa of inflammatory bowel disease. J Gastroenterol Hepatol 1999; 14: 987-996.

30. Woywodt A, Ludwig D, Neustock P, et al. Mucosal cytokine expression, cellular markers and adhesion molecules in inflammatory bowel disease. Eur J Gastroenterol Hepatol 1999; 11: 267-276.

31. Kusugami K, Fukatsu A, Tanimoto M, et al. Elevation of interleukin-6 in inflammatory bowel disease is macrophage- and epithelial cell-dependent. Dig Dis Sci 1995; 40: 949-959. 
32. Jones SC, Trejdosiewicz LK, Banks RE, Howdle PD, Axon AT, Dixon MF, Whicher JT. Expression of interleukin-6 by intestinal enterocytes. J Clin Pathol 1993; 46: 1097-1100.

33. Fukushima K, Sasaki I, Takahashi K, Naito H, Matsuno S. Lipopolysaccharide and proinflammatory cytokine-induced energy production in intestinal and colonic epithelial cell lines. Scand J Gastroenterol 1999 34: $291-296$.

34. Goodrich ME, McGee DW. Effect of intestinal epithelial cell cytokines on mucosal B-cell IgA secretion: enhancing effect of epithelial-derived IL-6 but not TGF-beta on IgA ${ }^{+}$B cells. Immunol Lett 1999; 67: 11-4.

35. Strong SA, Pizarro TT, Klein JS, Cominelli F, Fiocchi C. Proinflammatory cytokines differentially modulate their own, expression in human intestinal mucosal mesenchymal cells. Gastroenterology 1998; 14 $1244-1256$.

36. Fayyazi A, Sandau R, Duong LQ, et al. C5a receptor and interleukin-6 are expressed in tissue macrophages and stimulated keratinocytes but not in pulmonary and intestinal epithelial cells. Am J Pathol 1999; 54: 495-501.

37. Van Assche G, Barbara G, Deng Y, Lovato P, Gauldie J, Collins SM Neurotransmitters modulate cytokine-stimulated interleukin 6 secretion in rat intestinal smooth muscle cells. Gastroenterology 1999; 116: $346-$ 353.

38. Van Tol EA, Holt L, Li FL, et al. Bacterial cell wall polymers promote intestinal fibrosis by direct stimulation of myofibroblasts. Am J Physiol 1999; 277: G245-G255.

39. Khan L, Blennerhassett MG, Katacva GV, Collins SM. Interleukin 1 beta induces the expression of interleukin 6 in rat intestinal smooth muscle cells. Gastroenterology 1995; 108: 1720-1728.

40. Minta JO, Parnbrun L. In vitro induction of cytologic and functional differentiation of the immature human monocyte-like cell line U-937 with phorbol myristate acetate. Am J Pathol 1985; 119: 1-26.

41. Tsuchiya S, Kobayashi Y, Goto Y, Okumura H, Nakae S, Konno T, Tada K. Induction of maturation in cultured human monocytic leukemia cells by a phorbol diester. Cancer Res 1982; 2: 1530-1536.
42. Anderson KC, Lust JA. Role of cytokines in multiple myeloma. Semin Hematol 1999; 36(1 Suppl 3): 14-20.

43. Neipel F, Albrecht JC, Fleckenstein B. Human herpes virus 8 - the first human Rhadinovirus. J Natl Cancer Inst Monographs 1998; 23: 73-77.

44. Kapadia S, Dibbs Z, Kurrelmeyer K, et al. The role of cytokines in the failing human heart. Cardiol Clin 1998; 16: 645-656.

45. Carroll G, Bell M, Wang H, Chapman H, Mills J. Antagonism of the IL-6 cytokine subfamily - a potential strategy for more effective therapy in rheumatoid arthritis. Inflamm Res 1998; 47: 1-7.

46. Cross JT, Benton HP. The roles of interleukin-6 and interleukin-10 in B cell hyperactivity in systemic lupus erythematosus. J Clin Gastroenterol 1999; 20: 123-126.

47. Holtkamp W, Stollberg T, Reis HE. Serum interleukin-6 is related to disease activity but not disease specificity in inflammatory bowel disease. J Clin Gastroenterol 1995; 20: 123-126.

48. Reinisch W, Gasche C, Tillinger W, et al. Clinical relevance of serum interleukin- 6 in Crohn's disease; single point measurements, therapy monitoring, and prediction of clinical relapse. J Gastroenterol 1999; 94 2156-2164.

49. Gotteland M, Lopez M, Munoz C, Saez R, Altshiller H, Morens P, Brunser O. Local and systemic liberation of proinflammatory cytokines in ulcerative colitis. Dig Dis Sci 1999; 44: 830-835.

50. Holub MC, Mako E, Devay T, Dank M, Szalai C, Fenyvesi A, Falus A. Increased interleukin-6 levels, interleukin-6 receptor and gp130 expression in peripheral lymphocytes of patients with inflammatory bowel disease. Scand J Gastroenterol 1998; 228(Suppl): 47-50.

\section{Received 21 August 2002 \\ Accepted 29 October 2002}




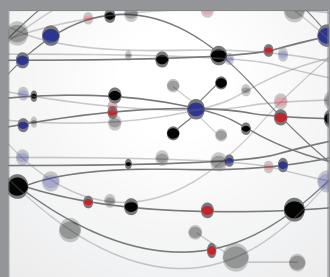

The Scientific World Journal
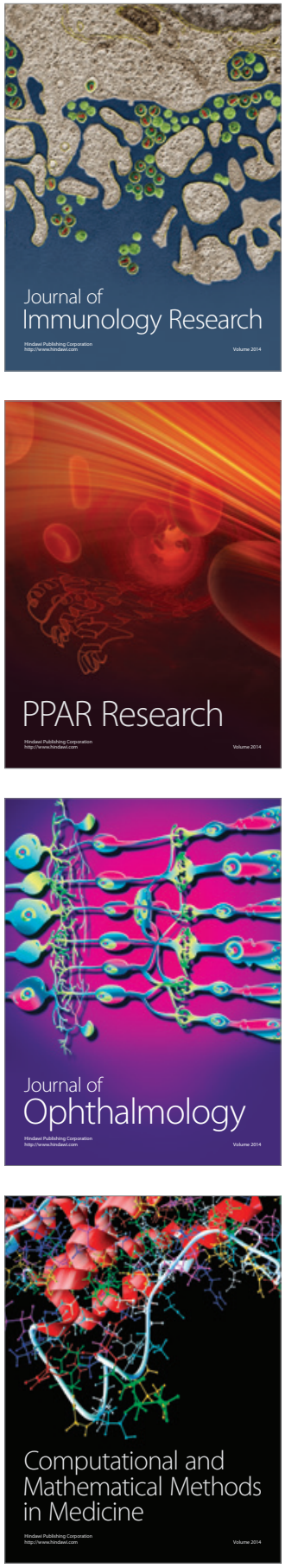

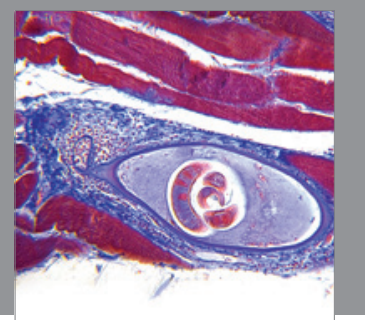

Gastroenterology

Research and Practice
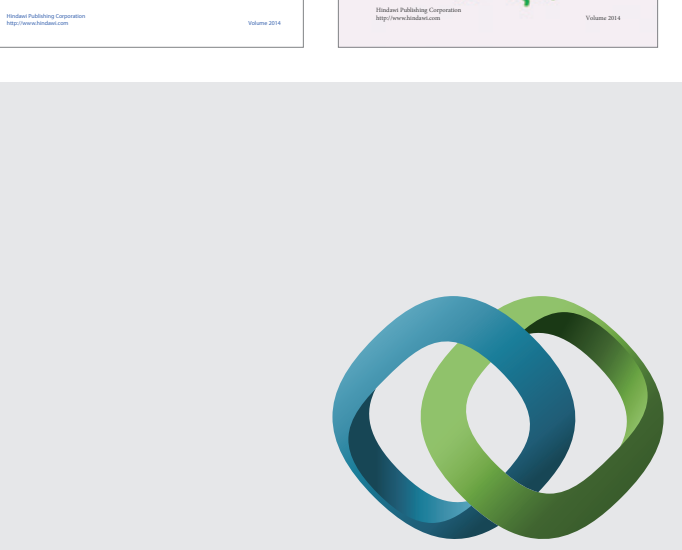

\section{Hindawi}

Submit your manuscripts at

http://www.hindawi.com
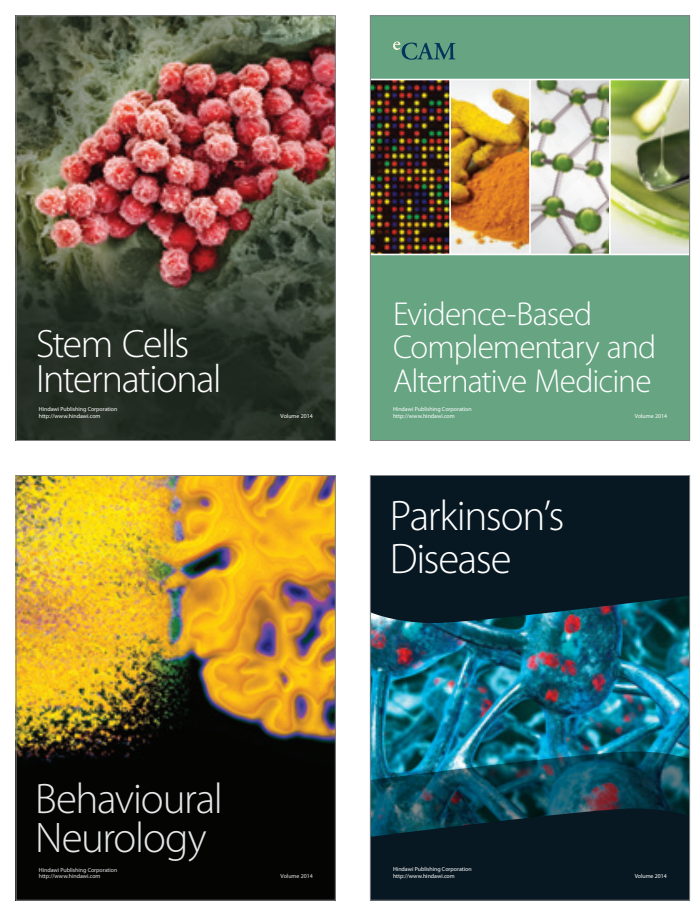

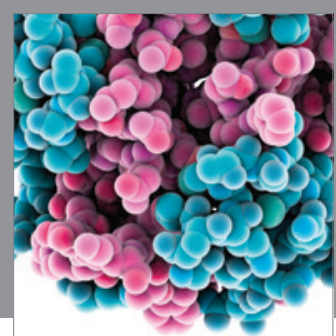

Journal of
Diabetes Research

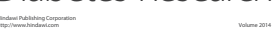

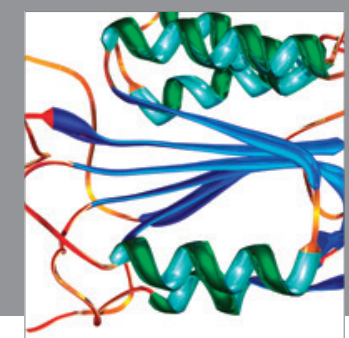

Disease Markers
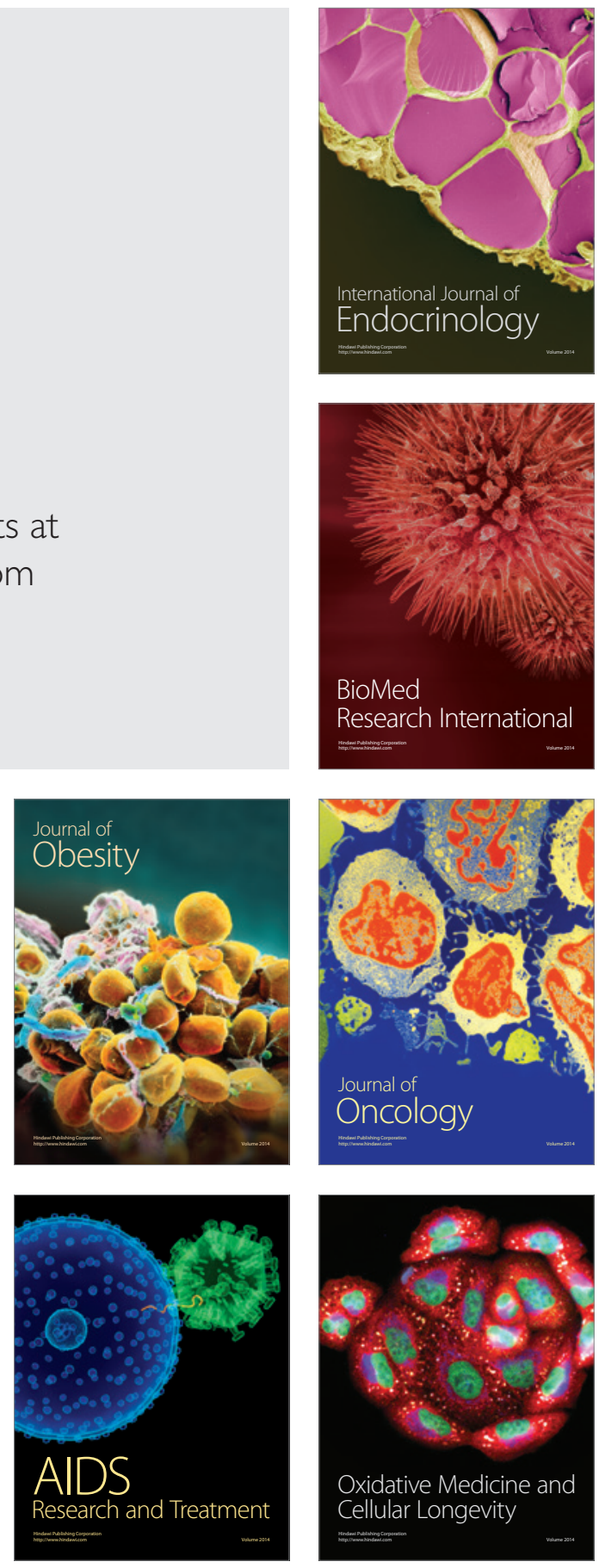